\title{
Bioactive Guided Fractions of Annona reticulata L. bark: Protection against Liver Toxicity and Inflammation through Inhibiting Oxidative Stress and Proinflammatory Cytokines
}

\author{
Raghuram Kandimalla', Suvakanta Dash ${ }^{2}$, Sanjeeb Kalita', Bhaswati Choudhury', \\ Sandeep Malampati ${ }^{3}$, Kasturi Kalita ${ }^{4}$ and Jibon Kotoky ${ }^{1 *}$ \\ ' Drug Discovery Laboratory, Life Sciences, Institute of Advanced Study in Science and Technology, Guwahati, India, \\ ${ }^{2}$ Girijananda Chowdhury Institute of Pharmaceutical Science, Guwahati, India, ${ }^{3}$ School of Chinese Medicine, Hong Kong \\ Baptist University, Hong Kong, China, ${ }^{4}$ Department of Pathology, Hayat Hospital, Guwahati, India
}

\section{OPEN ACCESS}

Edited by:

Lyndy Joy McGaw,

University of Pretoria, South Africa

Reviewed by:

Keliang Xie,

General Hospital of Tianjin Medical University, China

Fang-Rong Chang,

Kaohsiung Medical University, Taiwan

*Correspondence:

Jibon Kotoky

jkotoky@gmail.com

Specialty section: This article was submitted to

Ethnopharmacology,

a section of the journal

Frontiers in Pharmacology

Received: 08 March 2016

Accepted: 03 June 2016

Published: 22 June 2016

Citation:

Kandimalla R, Dash S, Kalita S, Choudhury B, Malampati S, Kalita K

and Kotoky J (2016) Bioactive

Guided Fractions of Annona reticulata

L. bark: Protection against Liver

Toxicity and Inflammation through Inhibiting Oxidative Stress

and Proinflammatory Cytokines.

Front. Pharmacol. 7:168.

doi: 10.3389/fphar.2016.00168
Herbal medicine is popularized worldwide due to its ability to cure the diseases with lesser or no side effects. North Eastern part of India comes under one of the world biodiversity hotspots which is very rich in traditional herbal medicine. Annona reticulata L. (Annonaceae) is one such plant used for the treatment of inflammatory diseases, liver ailments and diabetes by traditional healers. The present study was aimed to scientifically validate this folk knowledge and to develop an herbal remedy through evaluating bioactive guided fractions of $A$. reticulata (AR) bark against hepatotoxicity and inflammation using in vitro and in vivo models. Results of this study demonstrates that among all fractions of AR bark, methanol extract and its water fraction possess strong anti-oxidant ability and showed protection against $\mathrm{CCl}_{4}$ induced toxicity in $\mathrm{HepG} 2$ cell lines and rats. Both the fractions also exhibit dose dependent anti-inflammatory activity against carrageenan induced inflammation in rats. Water fraction showed potent response in the entire tests conducted than methanol extract, which states that polar components of the AR bark methanol extract were responsible for these activities. Further, from the experiments conducted to elucidate the mechanism of action, the results revealed that $A R$ bark showed liver protection and anti-inflammatory response through inhibiting the oxidative stress and inflammatory cytokines.

Keywords: antioxidant, liver toxicity, cytokines, inflammation, oxidative stress

\section{INTRODUCTION}

Reactive oxygen species (ROS) cause oxidative damage and lipid peroxidation in cells which can potentially leads to different diseases like cancer, inflammation, aging, heart problem, and severe liver damage (Ha et al., 2010; Chen et al., 2011). Liver is the second largest organ in the body which involves in vital functions like cleansing blood, vitamin synthesis, regulation of supply of body fuel, cholesterol regulation, balancing hormone regulation, and drug metabolism. Different ailments 
like virus, chemicals, and chronic alcoholism cause damage to the liver by producing vast number of ROS (Hou et al., 2013). More than 600 chemical substances can cause liver injury, among all carbon tetra chloride $\left(\mathrm{CCl}_{4}\right)$, paracetamol and ethanol are more predominant (Cengiz et al., 2013). Inflammation caused due to tissue damage through different stimuli like irritants and pathogen or due to physical injury. There are very few drugs available in the market for the treatment of liver ailments and inflammation with fewer side effects despite of its pharmacological action. In this regard, it is necessary to develop novel drug candidates with less or no side effects (Huang et al., 2012). Ayurvedic medicine is so popular worldwide because of its effective ness and lesser toxicity. Medicinal plants are the tremendous source of antioxidants and phytochemicals which have the ability to treat liver aliments and inflammation (Feng et al., 2011; Pareek et al., 2013). To decrease the side effects by the synthetic drugs in the market, scientists are now focusing on developing the herbal based remedy (Kuete and Efferth, 2010).

Antioxidant ability of the plant components can help to fight against different disease conditions like organ damage; inflammation and cancer etc., through ROS neutralization inside the body. Natural antioxidants are safer and healthy than synthetic antioxidants used in food materials (Su et al., 2009). Annona reticulata L. (Annonaceae) is a small tree commonly called as Ramphal, Bullock's heart and custard apple, native to India, West Indies and tropical America, mainly cultivated for fruit production. Traditionally this plant is used as antiparasitic, insecticide, antidiarrheic, and antidysenteric. Different plant parts of $A$. reticulata have been reported for anti-hyperglycemic, analgesic, cytotoxic, anti-prolifiratory, and CNS depressant activities (Chavan et al., 2014; Jamkhande and Wattamwar, 2015). This plant is a good source of different bioactive phytochemicals like acetogenins (Chang et al., 1998), cycloreticulins A and B, cyclooctapeptides, cycloreticulin C, glabrin A, cyclopeptides (Wele et al., 2009; Jamkhande et al., 2016). Stem bark of this plant contains different chemical constituents like dopamine, salsolinol, coclaurine, 16-a-hydroxy-(e)-kauran-19oic acid, diterpenes (e)-kaur-16-en-19-oic acid, reticullacinone, methyl-17-hydroxy-16-b-(e)-kauran-19-oate, rolliniastatin and molvizarin (Hisham et al., 1994; Nirmal et al., 2010; Bhalke and Chavan, 2011). A substantial amount of population of Assam, Arunachal Pradesh, and Nagaland of India are using bark of this plant to cure different liver ailments, inflammation and diabetes. To scientifically validate this claim and to develop an herbal drug remedy the present study aims to investigate the bioactive guided fractions of $A$. reticulata bark for antioxidant, hepatoprotective and anti-inflammatory activities using both in vitro and in vivo models.

\section{MATERIALS AND METHODS}

\section{Chemical and Drugs}

Cell culture media and related chemical obtained from Invitrogen, Life Technologies, USA. ELISA kits procured from R\&D Systems, USA. Biochemical kits purchased from Accurex Biomedical, Pvt. Ltd., Mumbai. All the other chemicals were analytical grade and obtained from Sigma-Aldrich, Co., St. Louis, MO, USA.

\section{Plant Collection and Identification}

Annona reticulata bark was collected from Kamrup district $\left(26.3333^{\circ} \mathrm{N}, 91.2500^{\circ} \mathrm{E}\right)$, Assam in the month of January, 2015. Plant was identified by a taxonomist at North East India Ayurvedic Institute, Guwahati. A voucher specimen number (1801/IASST/2014-15) was deposited at herbarium, Drug Discovery Laboratory, Institute of Advanced Study in Science and Technology for future reference.

\section{Extraction and Bioactive Guided Fractionation}

Annona reticulata bark (ARB) was dried at room temperature $\left(25-27^{\circ} \mathrm{C}\right)$ and grinded into a coarse powder. $10 \mathrm{~kg}$ of the dried powder was subjected to simple maceration with methanol for $72 \mathrm{~h}$. The A. reticulata bark methanol extract (ARBME) was concentrated under pressure using rota evaporator (Buchi, Switzerland) to yield dry residue of $500 \mathrm{gm}$. A part of methanol extract was subjected to gradual fractionation using different solvents of increasing polarity viz, hexane (ARBHF), chloroform (ARBCF), ethyl acetate (ARBEAF), and water (ARBWF). Briefly, $400 \mathrm{gm}$ of ARBME was suspended into one liter of hexane and stirred vigorously by using magnetic stirrer for $24 \mathrm{~h}$ at room temperature. Further the hexane fraction was collected through filtration and the undissolve residue was collected and dried to continue the further fractionation. After extracting with all the solvents, the remaining methanol residue was collected and dried (ARBMR). The schematic representation of bioactive guided fraction is shown in Figure 1. Main mother methanol extract and its five fractions were prepared for testing biological activity and stored in $4^{\circ} \mathrm{C}$. All the samples were tested within 3 months of extraction and thawed before use.

\section{In Vitro Antioxidant Activity DPPH Radical Scavenging Assay}

Diphenyl picryl hydrazine (DPPH) assay is widely used method to determine the ability of phytochemicals to neutralize the free radicals (Choudhury B. et al., 2016; Kalita H. et al., 2016). Briefly, $2.7 \mathrm{~mL}$ of $0.2 \mathrm{mM}$ DPPH solution was added to $0.3 \mathrm{~mL}$ of the plant extracts/fractions at various concentrations. The reaction mixture was vigorously shaken and incubated at room temperature for $1 \mathrm{~h}$; absorbance was measured at $517 \mathrm{~nm}$. The radical scavenging activity was calculated as follows: scavenging rate $=[(\mathrm{As}-\mathrm{Ai}) / \mathrm{As}] \times 100$, where As is the absorbance of pure DPPH and Ai is the absorbance of DPPH in the presence of various extracts. Ascorbic acid at different concentrations identical to the experimental samples was used as references.

\section{Reducing Power Assay}

The reducing power of the extracts was estimated by following (Oyaizu, 1986). Increased concentrations of $0.2 \mathrm{~mL}$ extracts were mixed with $2.5 \mathrm{~mL}$ of phosphate buffer $(0.2 \mathrm{M}, \mathrm{pH} 6.6)$ and $2.5 \mathrm{~mL}$ of potassium ferricyanide $(1 \%)$. After incubation at $50^{\circ} \mathrm{C}$ for $20 \mathrm{~min}, 2.5 \mathrm{~mL}$ of trichloroacetic acid (10\%) was added, and 


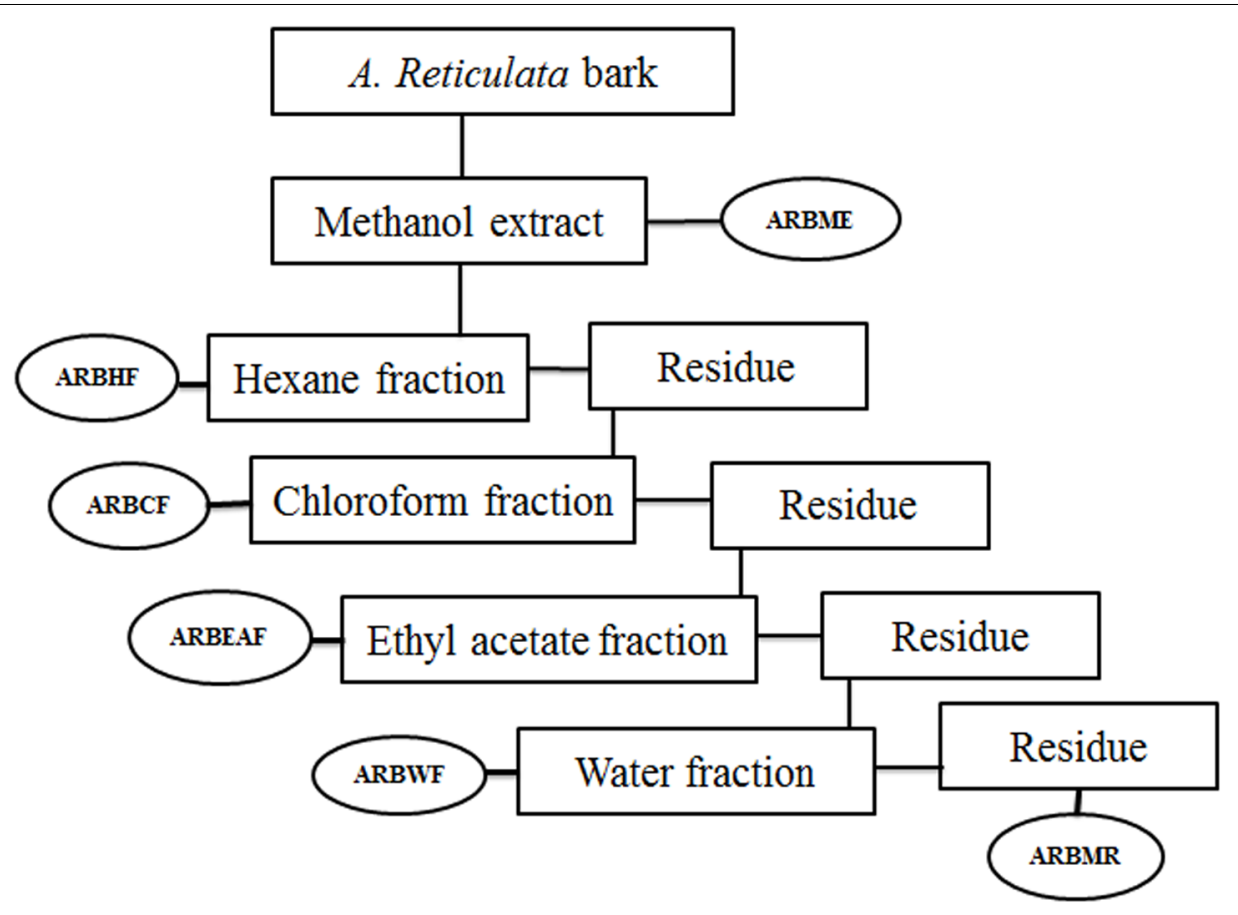

FIGURE 1 | Schematic representation of bioactive guided fractionation of Annona reticulata bark. ARBME, $A$. reticulata bark methanol extract; ARBHF, A. reticulata bark hexane fraction; $A R B C F, A$. reticulata bark chloroform fraction; ARBEAF, $A$. reticulata bark ethyl acetate fraction; ARBWF, $A$. reticulata bark water fraction; ARBMR, A. reticulata bark methanol residue.

each mixture was centrifuged at $1000 \mathrm{rpm}$ for $10 \mathrm{~min}$. Then, $2.5 \mathrm{~mL}$ of the supernatant was collected and mixed with $2.5 \mathrm{~mL}$ of deionized water and $0.5 \mathrm{~mL}$ of ferric chloride $(0.1 \%)$. The absorbance was measured at $700 \mathrm{~nm}$. The increased absorbance of the reaction mixture indicated increased reducing power. BHT was used as standards for comparison.

\section{Total Antioxidant Activity}

Measurement of total antioxidant capacity of plant extracts were performed by photochemiluminescence method in the Photochem instrument, Germany. The lipophilic and hydrophilic antioxidants were measured with the kits commercially available from Photochem, Germany. Total antioxidant activity of plant extracts was expressed in trolox equivalents for lipophilic antioxidants and ascorbic acid equivalents for hydrophilic antioxidants.

\section{Cell Culture}

Human liver hepatoma cells (HepG2) were obtained from National Center for Cell Sciences (NCCS), Pune, India. The cells were seeded $1 \times 10^{5}$ cells/ $\mathrm{T}_{25}$ flasks and cultured in DMEM containing low glucose with 10\% FBS and Penstrap (antibiotic solution) in $\mathrm{CO}_{2}$ Incubator at $37^{\circ} \mathrm{C}$. Stock culture was grown in $25 \mathrm{~cm}^{2}$ culture flasks and all experiments were done in 96 well plates (Life Technologies, USA).

\section{In vitro Cytotoxicity Assay}

Tetrazolium salt assay (MTT) was used to determine the cytotoxic concentration of plant fractions by following the method of Kalita S. et al. $(2015,2016)$ and Kandimalla et al. (2016). Briefly, the cells from the culture flask was trypsinized and seeded in 96-well plate at $5 \times 10^{3}$ cells/well and incubated in $\mathrm{CO}_{2}$ incubator at $37^{\circ} \mathrm{C}$ for $24 \mathrm{~h}$. After $24 \mathrm{~h}$ culture medium was replaced with new medium and ARBME, ARBWF $(5,25,50,125$, 250 , and $500 \mu \mathrm{g} / \mathrm{ml}$ ) at different concentrations. After $72 \mathrm{~h}$ of incubation in $\mathrm{CO}_{2}$ incubator at $37^{\circ} \mathrm{C}$, medium was removed and $20 \mu \mathrm{l}$ of $4 \mathrm{mg} / \mathrm{ml} \mathrm{MTT} \mathrm{(pH} \mathrm{7.4)} \mathrm{was} \mathrm{added} \mathrm{in} \mathrm{each} \mathrm{well.} \mathrm{Plate} \mathrm{was}$ incubated for 4 more hours and the supernatant was removed and $100 \mu \mathrm{l}$ of DMSO was added to each well and incubated for $30 \mathrm{~min}$ to dissolve the formed formazan. Absorbance was read at $570 \mathrm{~nm}$ by using micro plate reader (ThermoFisher, USA). The percentage growth inhibition was calculated by using the following formula:

$\%$ Growth inhibition =

$$
100-\left[\frac{\text { Mean OD of individual test group }}{\text { Mean OD of Control group }}\right] \times 100
$$

\section{Protective Effect of $A$. reticulata Fractions in $\mathrm{CCl} 4$}

\section{Induced Toxicity in HepG2 Cell Lines}

HepG2 cells at $1 \times 10^{5}$ cells/ml were adjusted with DMEM medium containing $10 \%$ fetal bovine serum. To each well of 96 well microtiter plate $0.1 \mathrm{ml}$ of diluted cell suspension was added and incubated at $37^{\circ} \mathrm{C}$ for $24 \mathrm{~h}$ in $\mathrm{CO}_{2}$ incubator. After $24 \mathrm{~h}$ of incubation the medium was discarded and expose the cells with different treatments they are as following: 


\section{Group-I (Control):}

Normal control: Cells were treated with $100 \mu \mathrm{l}$ of serum free culture medium for $24 \mathrm{~h}$.

DMSO control: Cells were treated with $100 \mu \mathrm{l}$ of serum free culture medium containing DMSO $(0.25 \% \mathrm{v} / \mathrm{v})$ for $24 \mathrm{~h}$.

Silymarin Control: Cells were treated with $100 \mu \mathrm{l}$ of serum free culture medium containing silymarin $(200 \mu \mathrm{g} / \mathrm{ml})$ for $24 \mathrm{~h}$.

ARBME Control: Cells were treated with $100 \mu \mathrm{l}$ of serum free culture medium containing ARBME $(200 \mu \mathrm{g} / \mathrm{ml})$ for $24 \mathrm{~h}$.

ARBWF control: Cells were treated with $100 \mu \mathrm{l}$ of serum free culture medium containing ARBWF $(200 \mu \mathrm{g} / \mathrm{ml})$ for $24 \mathrm{~h}$.

Group-II (CCl4 treatment): Cells were treated with $100 \mu \mathrm{l}$ of serum free culture medium containing 1.0\% (v/v) CCl4 for $24 \mathrm{~h}$.

Group-III (Standard treatment): Cells were treated with $100 \mu \mathrm{l}$ of serum free culture medium containing $1.0 \%(\mathrm{v} / \mathrm{v}) \mathrm{CCl} 4$ and silymarin at different concentrations $(50,100$, or $200 \mu \mathrm{g} / \mathrm{m})$ for $24 \mathrm{~h}$.

Group-IV (ARBME treatment): Cells were treated with $100 \mu \mathrm{l}$ of serum free culture medium containing $1.0 \%(\mathrm{v} / \mathrm{v}) \mathrm{CCl} 4$ and ARBME at concentration of $(50,100$, or $200 \mu \mathrm{g} / \mathrm{m})$ for $24 \mathrm{~h}$.

Group-V (ARBWF treatment): Cells were treated with $100 \mu \mathrm{l}$ of serum free culture medium containing $1.0 \%(\mathrm{v} / \mathrm{v}) \mathrm{CCl} 4$ and ARBWF at concentration of $(50,100$, or $200 \mu \mathrm{g} / \mathrm{m})$ for $24 \mathrm{~h}$.

\section{Cell Viability Assay}

Trypan blue exclusion assay (Rambabu and Vijayakumar, 2014) was performed to determine the cell viability. Briefly, after the exposure of cells to different treatment the cells from the wells were trypsinized and centrifuged at $1000 \mathrm{~g}$ for $10 \mathrm{~min}$ at $40^{\circ} \mathrm{C}$. The pellet was resuspended in $1 \mathrm{ml}$ ice cold PBS, then $0.1 \mathrm{ml}$ of cell suspension was mixed with $0.1 \mathrm{ml}$ of $0.2 \%$ trypan blue. Viable cells were counted using hemocytometer under lite microscope. Percentage of cell viability was calculated using the following formula-

$$
\% \text { viability }=
$$$$
\text { (Total number of cells - Trypan blue stained cells) }
$$

$$
\text { Total number of cells }
$$
$\times 100$

\section{Measurement of LDH}

After the drug treatment, HepG2 cells culture media from all the treatment groups were centrifuged at $2000 \mathrm{rpm}$ for $15 \mathrm{~min}$ and supernatant was collected to measure the LDH by Ecoline diagnostic kit. One unit of LDH activity is describe as the amount of enzyme that catalyzes the conversion of lactate to pyruvate to produce $1.0 \mu \mathrm{mol}$ of Nicotinamide adenine dinucleotide (NADH) per minute.

\section{Acute Toxicity Studies}

Acute oral toxicity studies were performed according to OECD guidelines to test chemicals. Swiss albino mice of either sex (five animals) was randomly selected were used for this study. Animal was kept overnight fasting with free access to water but not food, next day morning single dose of methanolic extract and active fraction of A. reticulata bark at $2000 \mathrm{mg} / \mathrm{kg}$ body weight were administered orally to three animals each. Animals were observed for 14 days, if mortality was observed in two out of three
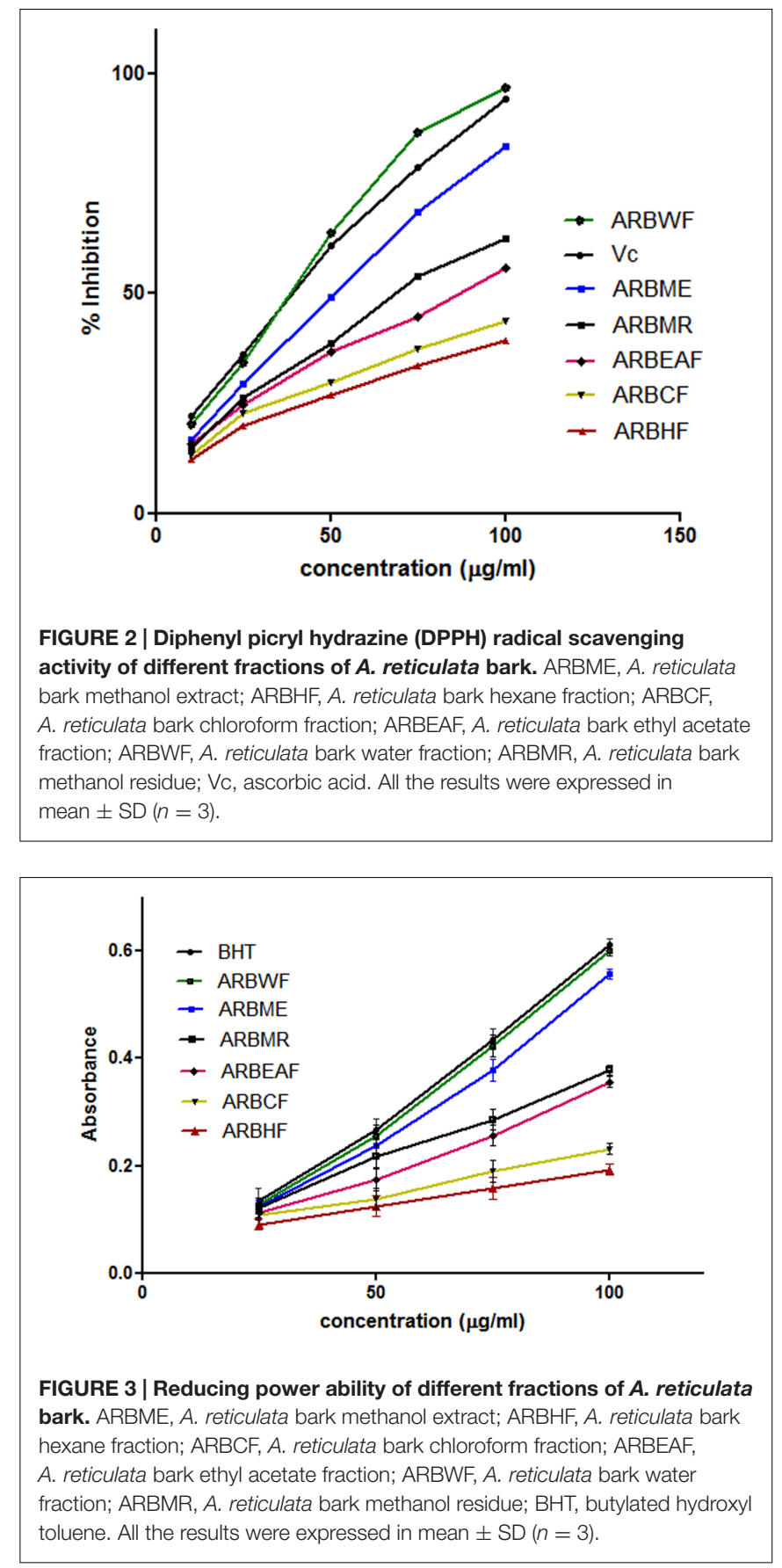

animals, then the dose was identified as toxic dose. If mortality was observed in one animal, experiment was repeat again with same dose to confirm the toxic dose. If mortality observed again experiment was continued with low doses $(300,50$, and $5 \mathrm{mg} / \mathrm{kg}$ body weight).

\section{Animals}

Adult male rats of Wistar strain weighing 150-200 g (Main experiment) and Swiss albino mice weighing 25-30 g (Acute toxicity studies) were obtained from the Institute of Advanced study in Science and Technology (IASST), Guwahati (India). 
Animals were maintained at $24^{\circ} \mathrm{C} \pm 1^{\circ} \mathrm{C}$, with relative humidity of $45-55 \%$ and $12: 12 \mathrm{~h}$ dark/light cycle and had free access to standard pellet diet (Provimi Animal Nutrition, Pvt. Ltd., India) and water throughout the experimental protocol. All experiments were carried out between 09:00 and 17:00 h. The experimental protocol was approved by the Institutional Animal Ethics Committee (IAEC) of IASST, Guwahati (IASST/IAEC/201415/746) and performed in accordance to the guidelines of Committee for Control and Supervision of Experimentation on Animals (CPCSEA).

\section{Effect of $A$. reticulata Active Fraction against $\mathrm{CCl}_{4}$ Induced Hepatotoxicity Experimental Design}

Adult male Wistar rats Total of 42 animals were randomly divided into seven groups of six animals in each group. All the drug treatment was continued for 14 days and on 14th day single dose of CCl4 $1.5 \mathrm{mg} / \mathrm{kg}$, in 1:1 dilution with olive oil was given in i.p. route.

Group I: Control animals (D.W for 14 days orally).

Group II: Toxic control ( $0.3 \%$ CMC for 14 days orally).

Group III: Standard group (Silymarin $100 \mathrm{mg} / \mathrm{kg}$ in $0.3 \%$ CMC for 14 days orally).

Groups IV and V: Treatment groups ARBME at 200 and $400 \mathrm{mg} / \mathrm{kg}$ in $0.3 \% \mathrm{CMC}$ for 14 days orally).

Groups VI and VII: Treatment groups ARBWF at 50 and $100 \mathrm{mg} / \mathrm{kg}$ in $0.3 \% \mathrm{CMC}$ for 14 days orally).

After $48 \mathrm{~h}$ of $\mathrm{CCl} 4$ administration all the animals was sacrificed and blood and liver was collected for biochemical estimation and histopathology analysis.

\section{Biochemical Estimation}

Blood was collected from retro-orbital route under mild anesthesia and allowed to clot and serum was separated by centrifugation at $3000 \mathrm{rpm}$ for $10 \mathrm{~min}$ and stored in $-80^{\circ} \mathrm{C}$ for further use. Serum biochemical enzymes like AST, ALT, ALP, and $\mathrm{LDH}$ levels was estimated by commercially available kits from Accurex, India as per the instructions given by the company. ELISA kits from R\&D Systems, USA was used to measure the serum TNF- $\alpha$, IL-1 $\beta$, and IL-10 levels. Each sample was done in duplicate and results were expressed in $\mathrm{Pg} / \mathrm{ml}$.

\section{Liver Biochemical Assays}

Liver homogenate was prepared with $50 \mathrm{mM}$ cold potassium phosphate buffer ( $\mathrm{pH}$ 7.4). The resulting suspension was centrifuged at $3000 \mathrm{rpm}$ for $15 \mathrm{~min}$ and supernatant was collected to measure the super oxide dismutase (SOD), catalase (CAT) by using assay kits from Cayman, USA as per the instructions given by the manufacturer and thiobarbituric acid reacting substances (TBARS) by Xia et al. (2013).

\section{Histopathology Examination}

Liver tissues were collected in $10 \%$ buffered formaldehyde from animals in different treatment groups and preserved at least for $24 \mathrm{~h}$. After dehydration gradually with ethanol (70-100\%), tissue was cleared in xylene and embedded in paraffin to make blocks. Sections $(5 \mu \mathrm{m})$ was prepared by a Leica RM 2016 rotary microtome (Leica Instruments, Ltd., Shanghai, China) and stained with hematoxylin and eosin. Slides were examined under microscope (Leica Microsystems Digital Imaging, Germany) at $10 \mathrm{x}$ magnification to observe the histopathological changes (Bhardwaj et al., 2016; Choudhury A.J. et al., 2016).

\section{Effect of $A$. reticulata Fractions against Carrageenan Induced Paw Edema}

Thirty six male adult wistar rats were randomly divided into six groups of six animals in each group. Animals kept overnight fasting with free access to water. Inflammation was induced in animals by injecting $0.05 \mathrm{ml}$ of $1 \%$ carrageenan (Intraplantar route) to right hind paw. Following drug treatment was given to the animals $1 \mathrm{~h}$ prior to carrageenan injection:

Group I: Control animals (0.3\% CMC orally).

Group II: Treatment with $10 \mathrm{mg} / \mathrm{kg}$ indomethacin orally.

Groups III and IV: Treatment with ARBME 200 and 400 mg/kg orally.

Groups V and VI: Treatment with ARBWF 50 and $100 \mathrm{mg} / \mathrm{kg}$ orally.

Paw volume was measured at $0,1,3$, and $5 \mathrm{~h}$ after the induction of inflammation by water plethysmometer (Harvard apparatus, Panlab, Spain). After taking the readings, blood was collected to measure the serum inflammatory markers and all the animals were sacrificed.

\section{Measurement of Inflammatory Cytokine Levels}

Blood was centrifuged at $1000 \mathrm{rpm}$ for $10 \mathrm{~min}$ to separate the serum. Serum inflammatory cytokines like TNF- $\alpha$, Il-1 $\beta$, and IL10 levels were measured using commercially available kits from R\&D Systems, USA by following manufactures guidelines. All the experiments were carried out at $4^{\circ} \mathrm{C}$ and results were presented in $\mathrm{pg} / \mathrm{ml}$.

\section{Statistical Analysis}

All the results were expressed as mean \pm SD. One way ANOVA followed by Tukey's multiple comparison tests was used to compare the different parameters between the groups. A Pvalue $<0.05$ was considered as significant. Graphpad prism 6 software was used to perform the statistical analysis.

\section{RESULTS AND DISCUSSION}

\section{In Vitro Anti-oxidant Activity of A. reticulata Fractions DPPH Assay}

This assay is based on the ability of the substance to reduce the stable DPPH free radical to DPPH. Scavenging ability of the antioxidant substance on DPPH is widely accepted method (Liu et al., 2013). The scavenging ability of the A. reticulata extract and fractions were given in Figure 2. All the fractions exhibited dose dependent radical scavenging ability. Among all the fractions ARBWF showed maximum response and ARBHF showed the lowest response. From these findings it is suggested that both ARBME and ARBWF have strong antioxidant property. 


\section{Reducing Power Assay}

Reducing power of the substance directly related with its antioxidant ability (Meir et al., 1995). To measure the reducing ability, transformation of $\mathrm{Fe}^{3+}$ to $\mathrm{Fe}^{2+}$ was taken into the consideration, which can be measured spectrophotometrically. Reducing power ability of $A$. reticulata extract and fractions were increased directly proportional to the concentration (Figure 3). ARBME and ARBWF showed promising results, where water fraction showed potent response. Among all the fractions tested ARBME and ARBWF showed potent renounce, so we further evaluated the biological activity of only these two fractions.

\section{Total Antioxidant Activity}

Photo-chemi-luminescence method in the Photochem instrument was dependent on the antioxidant concentration based on the Guldberg-Waage law, which expresses the magnitude of the reaction. Reactions of radicals with antioxidants give relatively stable products which are measurable. Antioxidant capacity of the drug/substance depends on the concentration (Hic and Balic, 2012). Total antioxidant activity of methanol extract and water fraction of $A$. reticulata bark found to be $57.34 \mathrm{nmol}$ trolax equivalents and $87.16 \mathrm{nmol}$ ascorbic acid equivalents respectively.

TABLE 1 | Protective effect of ARBME and ARBWF against $\mathrm{CCl}_{4}$ intoxicated HepG2 cell lines.

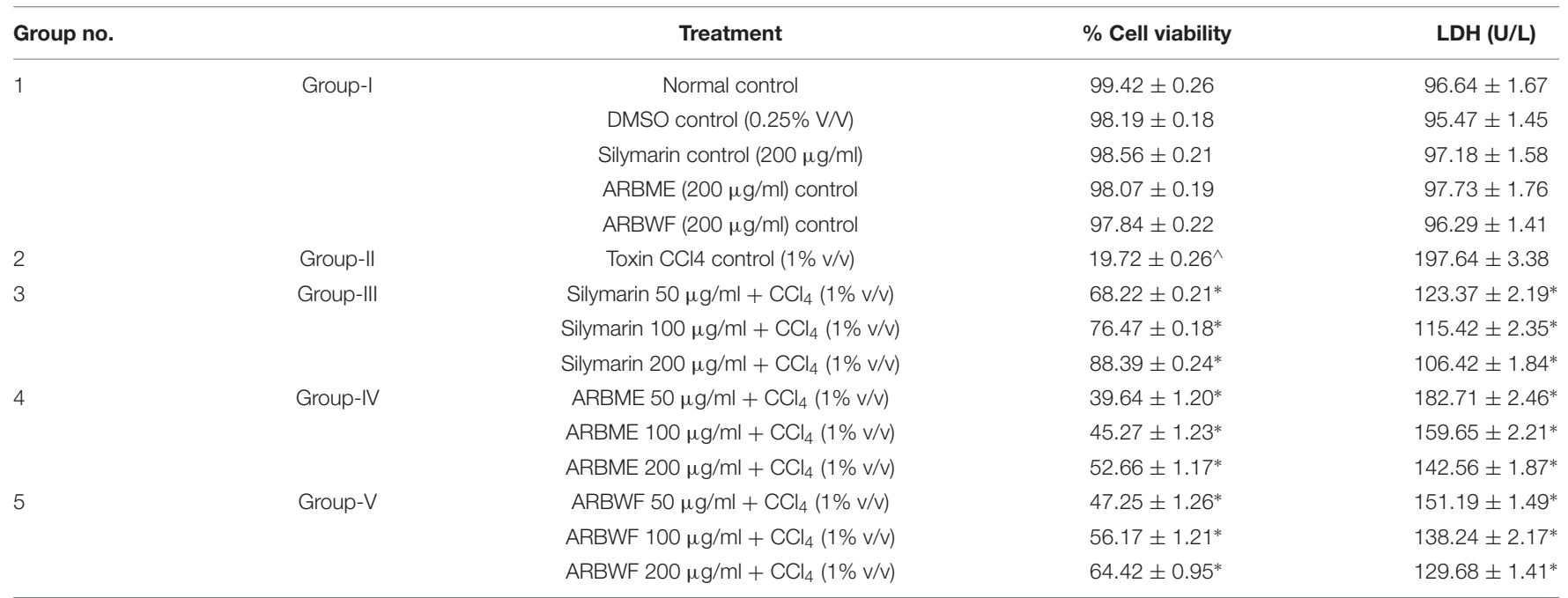

All the results were expressed in mean $\pm S D(n=3) . \wedge P<0.05$ in comparison of group-ll with group-l. $* P<0.05$ in comparison of groups-III, $I V$, and $V$ with group-ll. $A R B M E, A$. reticulata bark methanol extract; ARBWF, A. reticulata bark water fraction.

TABLE 2 | Effect of different drug treatment on serum and liver enzyme levels of $\mathrm{CCl}_{4}$ intoxicated rats.

Group no. Group
Serum levels of

\begin{tabular}{|c|c|c|c|c|c|c|}
\hline AST (IU/I) & ALT (IU/I) & ALP (IU/I) & LDH (U/I) & SOD (U/ml) & $\begin{array}{c}\text { CAT } \\
(\mathrm{nmol} / \mathrm{min} / \mathrm{ml})\end{array}$ & $\begin{array}{c}\text { TBARS (nmol/g } \\
\text { tissue) }\end{array}$ \\
\hline $41.6 \pm 2.8$ & $38.3 \pm 2.4$ & $94.5 \pm 3.2$ & $436.8 \pm 15.4$ & $9.8 \pm 1.1$ & $5.2 \pm 0.8$ & $158.5 \pm 8.7$ \\
\hline $124.2 \pm 6.1^{\$ \$ \$}$ & $96.7 \pm 5.8^{\$ \$ \$}$ & $197.5 \pm 9.7^{\$ \$ \$}$ & $1022.9 \pm 29.2^{\$ \$ \$}$ & $1.9 \pm 0.4^{\$ \$ \$}$ & $0.8 \pm 0.1^{\$ \$ \$}$ & $342.8 \pm 12.6^{\$ \$ \$}$ \\
\hline $52.8 \pm 4.4^{* * *}$ & $44.6 \pm 3.5^{* * *}$ & $108.2 \pm 7.8^{* * *}$ & $471.4 \pm 20.6^{* * *}$ & $7.7 \pm 0.8^{* * *}$ & $4.6 \pm 0.5^{* * *}$ & $171.8 \pm 9.4^{* * *}$ \\
\hline $72.7 \pm 5.3^{* * *}$ & $59.9 \pm 3.8^{* * *}$ & $132.4 \pm 7.2^{* * *}$ & $563.8 \pm 18.5^{* * *}$ & $3.8 \pm 0.7^{* * *}$ & $3.2 \pm 0.4^{* *}$ & $213.4 \pm 11.8^{* * *}$ \\
\hline $63.4 \pm 4.8^{* * *}$ & $53.4 \pm 4.1^{* * *}$ & $121.8 \pm 9.6^{* * *}$ & $509.4 \pm 16.6^{* * *}$ & $5.6 \pm 1.1^{* * *}$ & $3.9 \pm 0.6^{* * *}$ & $186.1 \pm 8.6^{* * *}$ \\
\hline $67.6 \pm 5.4^{* * *}$ & $53.9 \pm 4.7^{* * *}$ & $126.9 \pm 8.5^{* * *}$ & $530.7 \pm 19.2^{* * *}$ & $5.1 \pm 0.9^{* * *}$ & $3.8 \pm 0.4^{* * *}$ & $194.5 \pm 9.7^{* * *}$ \\
\hline $57.3 \pm 3.9^{* * *}$ & $45.1 \pm 3.6^{* * *}$ & $111.2 \pm 8.8^{* * *}$ & $494.3 \pm 21.2^{* * *}$ & $6.8 \pm 0.9^{* * *}$ & $4.5 \pm 0.7^{* * *}$ & $178.6 \pm 10.5^{* * *}$ \\
\hline
\end{tabular}

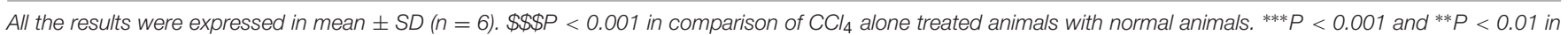
comparison of drug treated animals with $\mathrm{CCl}_{4}$ alone treated animals. ARBME, $A$. reticulata bark methanol extract; ARBWF, A. reticulata bark water fraction. 


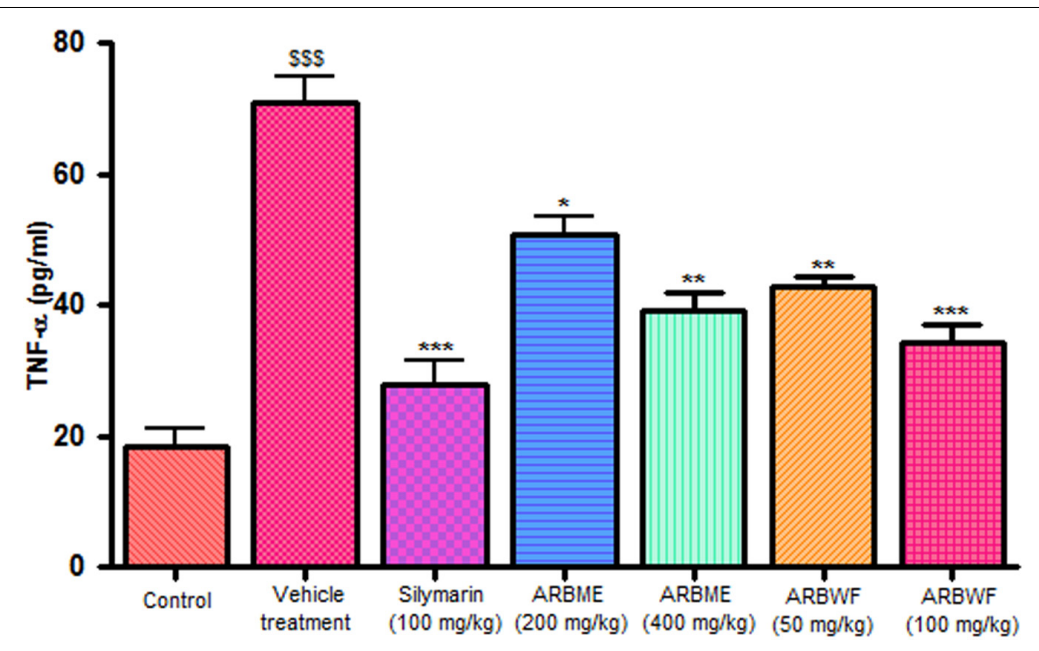

FIGURE 4 | Effect of different drug treatment on serum TNF- $\alpha$ levels. All the results were expressed in mean \pm SD $(n=6)$. $\$ \$ \$ P<0.001$ in comparison of $\mathrm{CCl}_{4}$ alone treated animals with normal animals. ${ }^{* *} P<0.001,{ }^{* *} P<0.01$, and ${ }^{*} P<0.05$ in comparison of drug treated animals with $\mathrm{CCl}{ }_{4}$ alone treated animals. ARBME, A. reticulata bark methanol extract; ARBWF, A. reticulata bark water fraction.

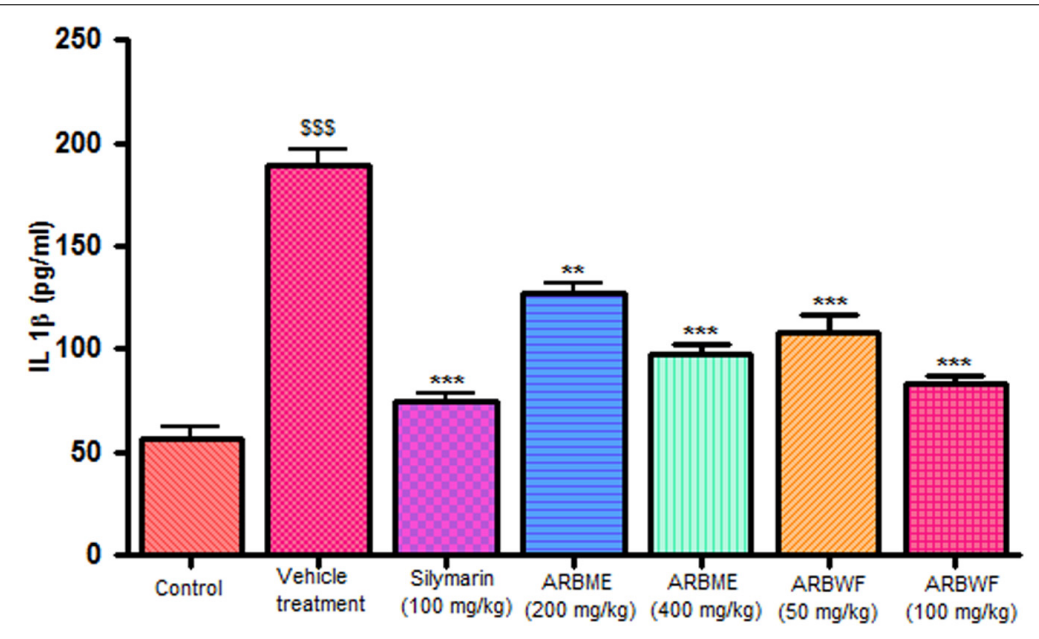

FIGURE 5 | Effect of different drug treatment on serum IL-1 $\beta$ levels. All the results were expressed in mean $\pm \mathrm{SD}(n=6)$. $\$ \$ \$ P<0.001$ in comparison of CCl alone treated animals with normal animals. ${ }^{* *} P<0.001$ and ${ }^{* *} P<0.01$ in comparison of drug treated animals with $\mathrm{CCl}_{4}$ alone treated animals. ARBME,

A. reticulata bark methanol extract; ARBWF, A. reticulata bark water fraction.

\section{Cytotoxicity Effect of ARBME and ARBWF in HepG2 Cells}

Both ARBME and ARBWF did not show significant difference on percentage growth inhibition up to $250 \mu \mathrm{g} / \mathrm{ml}$. At large dose $500 \mu \mathrm{g} / \mathrm{ml}$ both the fractions showed growth inhibits the HepG2 cell growth, so we selected 50,100, and $200 \mu \mathrm{g} / \mathrm{ml}$ to evaluate the hepato protective response of ARBME and ARBWF.

\section{Cytoprotective Effect of ARBME and ARBWF in $\mathrm{CCl}_{4}$ Induced Toxicity on HepG2 Cells}

Table 1 shows the effect of different drug treatments on $\mathrm{CCl}_{4}$ intoxicated HepG2 cell lines. On exposure to $\mathrm{CCl}_{4}$ cell viability was significantly decreased and LDH levels were significantly raised. Cells on treatment with ARBME and ARBWF showed protection from $\mathrm{CCl}_{4}$ dose dependently which can be confirmed by increased in cell viability and decreased LDH levels. HepG2 cell model is widely used model to study hepatoprotective activity of xenobiotics, because of its resemblance to human hepatocytes (Krithikaa et al., 2009). The extent of damage to cells on exposure to $\mathrm{CCl} 4$ was determined by measuring the cell leakage enzyme like LDH. Here in this study LDH levels were significantly decrease and cell viability increased in ARBME and ARBWF treated groups compared to $\mathrm{CCl} 4$ alone treated group. This in vitro result explains the hepatoprotective activity of the ARBME and ARBWF, water fraction of methanol extract showed potent activity than methanol extract. Both ARBME and ARBWF was found to be non-toxic toward HepG2 cells, we further evaluated its activity in in vivo models. 


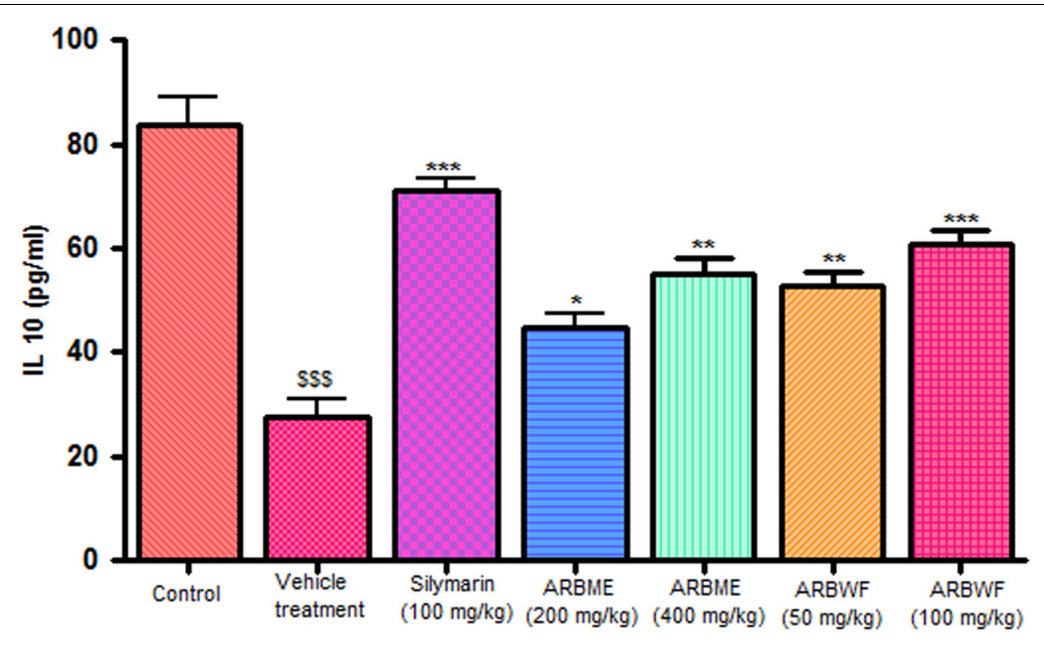

FIGURE 6 | Effect of different drug treatment on serum IL-10 levels. All the results were expressed in mean $\pm \mathrm{SD}(n=6)$. $\$ \$ \$ P<0.001$ in comparison of $\mathrm{CCl} 4$ alone treated animals with normal animals. ${ }^{* *} P<0.001,{ }^{*} P<0.01$, and ${ }^{*} P<0.05$ in comparison of drug treated animals with $\mathrm{CCl}_{4}$ alone treated animals. ARBME, A. reticulata bark methanol extract; ARBWF, A. reticulata bark water fraction.

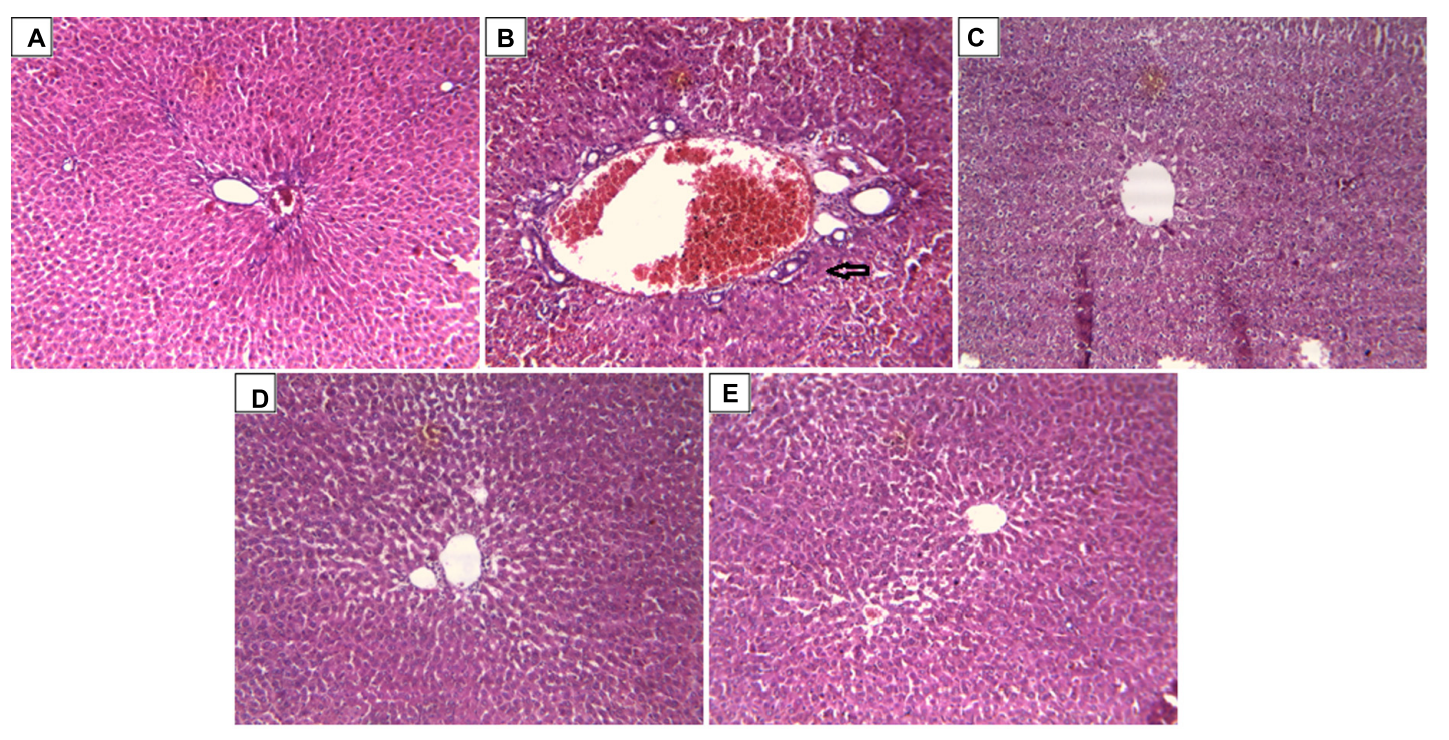

FIGURE 7 | Effect of drug treatment on liver histopathology of $\mathbf{C C l}_{\mathbf{4}}$ intoxicated rats. (A) Liver of control rat with no $\mathrm{CCl}{ }_{4}$ treatment showing normal hepatocytes with no inflammatory cell infiltrate; $x 10$. (B) Liver of rat treated with $\mathrm{CCl} 4$ showing formation of bridging necrosis with chronic inflammatory cells; $\mathrm{x} 10$. (C) Liver of rat treated with $\mathrm{CCl} 4$ and $100 \mathrm{mg} / \mathrm{kg}$ silymarin showing normal hepatocytes with no inflammation and necrosis; $\mathrm{x} 10$. (D) Liver of rat treated with CCl4 and $400 \mathrm{mg} / \mathrm{kg}$ of ARBME showing mild periportal inflammation and no necrosis; $\mathrm{x} 10$. (E) Liver of rat treated with CCl4 and $100 \mathrm{mg} / \mathrm{kg}$ ARBWF showing absence of inflammatory cells or necrosis; x10. ARBME, A. reticulata bark methanol extract; ARBWF, A. reticulata bark water fraction.

\section{Acute Toxicity Studies}

ARBME and ARBWF at $2000 \mathrm{mg} / \mathrm{kg}$ did not show any effect on respiratory rate, heart rate, body temperature, salivation, corneal reflex, locomotor activity, body tone, skin tone, grip strength, abdominal tone, tremors, piloerection, tail elevation, twitches, and convulsions are also not observed. No mortality was observed after 14 days of observation period in tested mice. ARBME and ARBWF were found to be non-toxic to animals, so we further evaluated the hepatoprotective and anti-inflammatory activity of same using appropriate animal models.

\section{Hepatoprotective Activity of ARBME and ARBWF against $\mathrm{CCl}_{4}$ Induced Hepatic Damage \\ Effect of Drug Treatment on Serum Hepatobiliary Enzyme Levels}

Hepato toxins cause damage to the plasma membrane of hepatocytes and cause liver toxicity. $\mathrm{CCl}_{4}$ is well-known hepatotoxic to induce liver damage in laboratory animals. Active metabolite $\left(\mathrm{CCl}_{3 \bullet}\right)$ is mainly associated with hepatotoxicity 


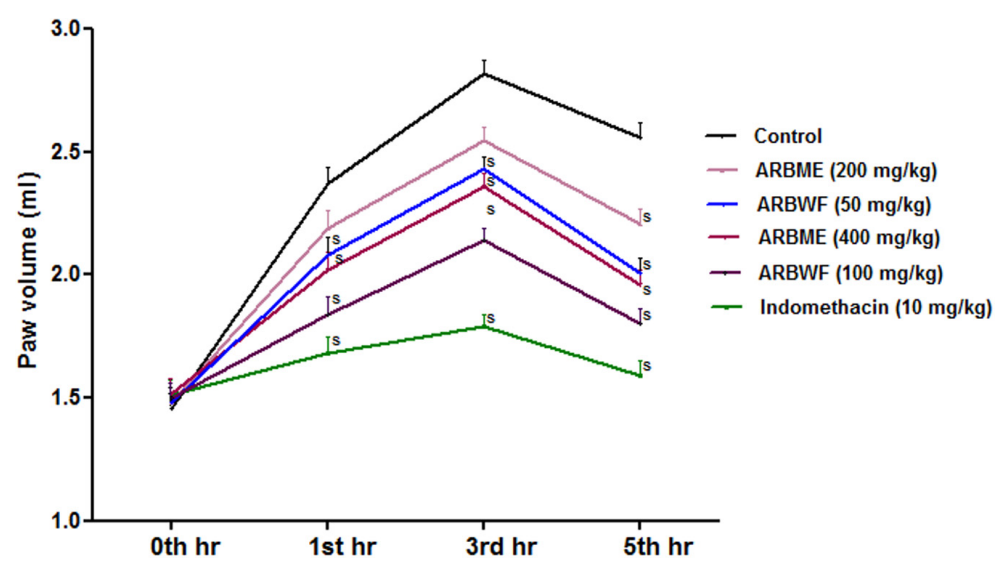

FIGURE 8 | Effect of $\boldsymbol{A}$. reticulata bark fractions on carrageenan induced paw edema over $\mathbf{5} \mathbf{h}$. All the results were expressed in mean $\pm \mathrm{SD}(n=6)$. $\mathrm{S}$ $P<0.05$ in comparison of drug treated animals with saline treated animals. ARBME, $A$. reticulata bark methanol extract; ARBWF, A. reticulata bark water fraction.

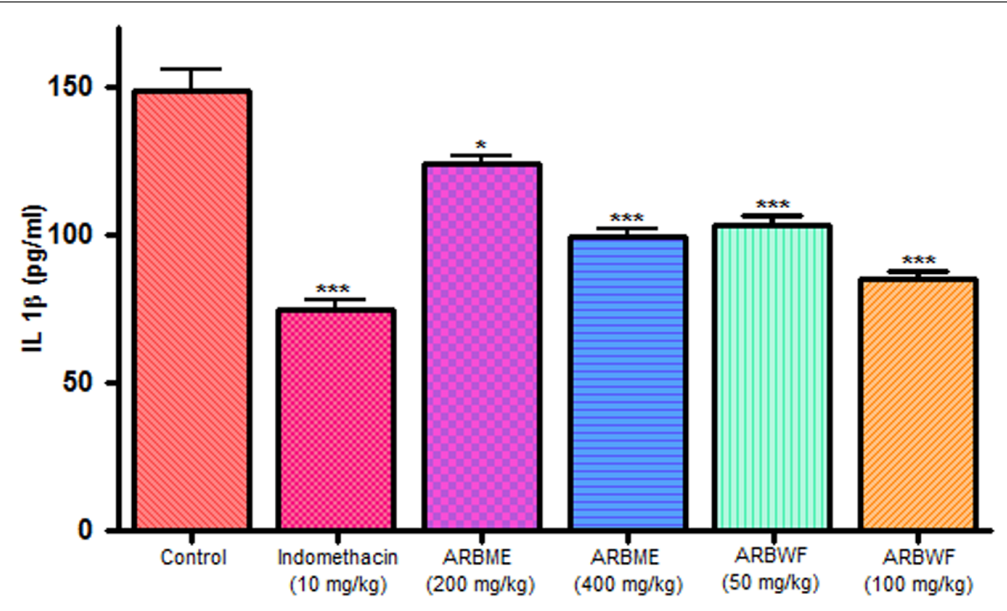

FIGURE 9 | Effect of different drug treatment on serum IL-1 $\beta$ levels of carrageenan induced paw edema rats. All the results were expressed in mean \pm SD $(n=6) .{ }^{* * *} P<0.001$ and ${ }^{*} P<0.05$ in comparison of drug treated animals with saline treated animals. ARBME, A. reticulata bark methanol extract; ARBWF,

A. reticulata bark water fraction.

induced by $\mathrm{CCl}_{4}$. This $\left(\mathrm{CCl}_{3 \bullet}\right)$ radical covalently binds with sulfhydryl groups of protein thiols in hepatocytes and cause lipid peroxidation and necrosis. During this necrotic stage hepatobiliary enzymes releases into blood circulation, which shows increase levels in serum (Vuda et al., 2012). $\mathrm{CCl}_{4}$ alone treated animals showed raised levels of all serum biochemical markers. Standard drug silymarin, ARBME and ARBWF restored the elevated levels of serum AST, ALT, ALP, and LDH levels due to $\mathrm{CCl}_{4}$ toxicity. ARDWF showed more potent activity than ARBME, but the response is not up to standard drug activity. The results of hepatoprotective activity of ARBME and ARBWF were summarized in Table 2.

\section{Effect of Drug Treatment on Lipid Peroxidation and Liver Anti-Oxidant Enzymes}

Thiobarbituric acid reacting substances are the end products of lipid peroxidation, high levels of these substances inside the body is a marker to liver injury. SOD and catalase are the antioxidant defense enzymes that protect liver from free radicals and inhibit the lipid peroxidation. $\mathrm{CCl}_{4}$ treatment cause significant decrease in these antioxidant enzymes and cause the lipid peroxidation (Cheng et al., 2013). Treatment with standard drug silymarin, ARBME and ARBWF significantly increases the levels of SOD and catalase and inhibits the lipid peroxidation (Table 2). Results of this study clearly demonstrate the hepatoprotective activity of ARBME and ARBWF. The water fraction (ARBWF) showed potent response than methanol extract (ARBME), which states that polar compounds of $A$. reticulata bark was responsible for the hepatoprotective response.

\section{Effect of Drug Treatment on Cytokine Levels}

$\mathrm{CCl}_{4}$ induction activates inflammatory cytokines TNF- $\alpha$, IL-1 $\beta$ and decrease anti-inflammatory cytokine IL-10 levels in in vivo system. $\mathrm{CCl}_{4}$ metabolism stimulated the Kupffer cells which activates this TNF- $\alpha$ and IL- $1 \beta$. IL- $1 \beta$ is strong inflammatory cytokines which involves in the production of prostaglandins, 


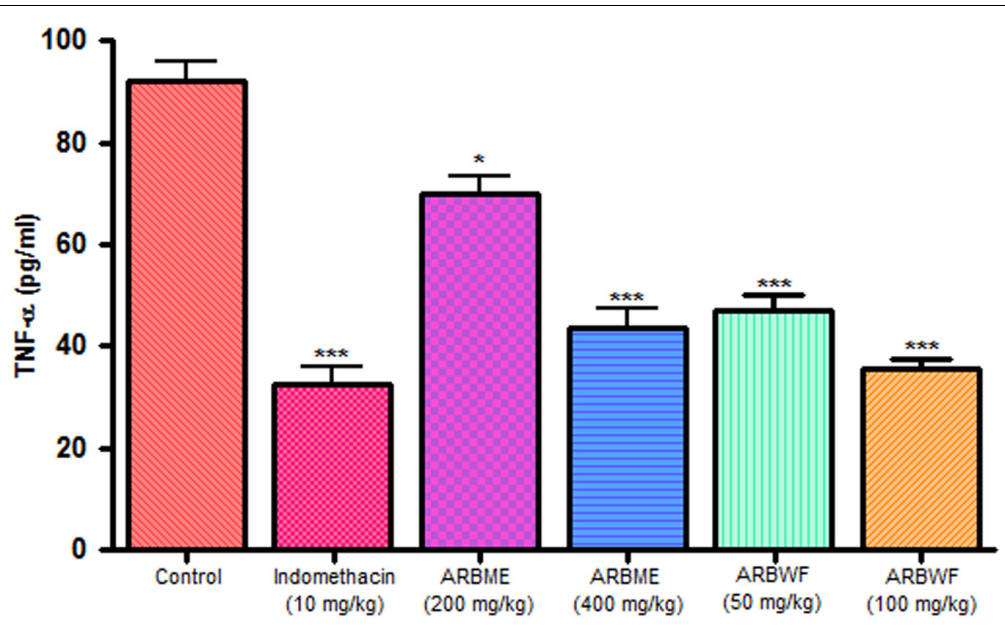

FIGURE 10 | Effect of different drug treatment on serum TNF- $\alpha$ levels of carrageenan induced paw edema rats. All the results were expressed in mean $\pm \mathrm{SD}(n=6) .{ }^{* *} P<0.001$ and ${ }^{*} P<0.05$ in comparison of drug treated animals with saline treated animals. ARBME, A. reticulata bark methanol extract; ARBWF, $A$. reticulata bark water fraction.

macrophage activation and neutrophil infiltration. This activation of inflammatory cytokine cascade produces significant damage to the liver cells (Edwards et al., 1993; Ishiyama et al., 1995). Pretreatment with standard drug silymarin, ARBME and ARBWF before $\mathrm{CCl}_{4}$ induction significantly inhibits the TNF- $\alpha$ (Figure 4), IL-1 $\beta$ (Figure 5) production and IL-10 (Figure 6) destruction in animals. ARBWF showed potent response to ARBMF which confirms that polar compounds of ARB possess anti-inflammatory activity mediated hepatoprotective response.

\section{Effect of Drug Treatment on Histopathology of $\mathrm{CCl}_{4}$ Intoxicated Rat Liver}

In support to the hepatoprotective activity of ARBME and ARBWF, histopathology of liver tissue was performed and analyzed. Liver tissue of control animals showed normal hepatocytes with no inflammatory cell infiltrate (Figure 7A). $\mathrm{CCl}_{4}$ intoxication causes demolishment of hepatocytes which was evidenced by formation of bridging necrosis, collagen accumulation, large septa and chronic inflammation (Figure 7B). Standard drug silymarin treated group, ARBME (400 mg/kg) and ARBWF (100 mg/kg) pretreated animals showed significant protection from the $\mathrm{CCl}_{4}$, where normal tissue architecture with no necrosis and mild inflammation was observed (Figures 7C-E). From this evidence the present study confirms the hepatoprotective ability of ARB. Compared to ARBME the dose of ARBWF is less which states that, the later one is potent than earlier.

\section{Effect of Drug Treatment on Carrageenan Induced Paw Edema}

\section{Paw Volume}

Carrageenan induced inflammation in experimental animals is the widely used model to test the orally injected antiinflammatory agents/drugs. Inflammation process takes place in two phases, in initial phase histamine and serotonin releases and second phase involves the activation of prostaglandins and lysosomal bodies which are the prime target of most of antiinflammatory agents (Marroquin-Segura et al., 2009). Standard drug indomethacin, ARBME and ARBWF significantly decrease the carrageenan induced paw edema in rats (Figure 8) Further ARBWF showed potent response to ARBME which demonstrate that polar chemical components of $\mathrm{ARB}$ were responsible for this action.

\section{Serum Cytokine Levels}

As discussed previously pro inflammatory cytokines like IL-1 $\beta$ and TNF- $\alpha$ plays a major role in inflammation process through activation of the prostaglandin and macrophages. Carrageenan injection cause notable rise in IL- $\beta$ and TNF- $\alpha$ levels and standard drug indomethacin, ARBME and ARBWF treated animals inhibits the production of these cytokines (Figures 9 and 10). Our findings demonstrate the anti-inflammatory ability of ARB.

\section{CONCLUSION}

The present study demonstrates the antioxidant, hepatoprotective and anti- inflammatory ability of bioactive guided fractions of $A$. reticulata bark. Methanol extract of $\mathrm{ARB}$ and its water fraction showed strong antioxidant activity and hence further evaluated for biological activity. Both the fractions exhibited significant hepatoprotection and antiinflammatory response in both in vitro and in vivo studies. The phyto constituents of ARB potentially reduced the oxidative stress and inflammatory cytokines to yield the therapeutic response. ARBWF showed potent response in all the tests conducted, so from this study it can be concluded that polar chemical components of $A$. reticulata bark like 16-a-hydroxy(e)-kauran-19-oic acid, diterpenes (e)-kaur-16-en-19-oic acid, reticullacinone, methyl-17-hydroxy-16-b-(e)-kauran-19-oate, 
rolliniastatin and molvizarin might be responsible for the obtained pharmacological activity. ARBWF can be used to prepare the herbal formulations for the treatment of liver aliments and inflammation related diseases. Successful isolation and biological screening of the chemical component responsible for the activity can potentially contribute toward development of novel drug entity which is undergoing in our laboratory.

\section{AUTHOR CONTRIBUTIONS}

Mr. RK designed the whole study and performed all the in vitro and in vivo experiments and wrote the manuscript. Mr. SK,

\section{REFERENCES}

Bhalke, R. D., and Chavan, M. J. (2011). Analgesic and CNS depressant activities of extracts of Annona reticulata Linn. bark. Phytopharmacology 1, 160-165.

Bhardwaj, N., Singh, Y. P., Devi, D., Kandimalla, R., Kotoky, J., and Mandal, B. B. (2016). Potential of silk fibroin/chondrocyte constructs of muga silkworm Antheraea assamensis for cartilage tissue engineering. J. Mater. Chem. B 4, 3670-3684. doi: 10.1039/C6TB00717A

Cengiz, N., Kavak, S., Güzel, A., Ozbek, H., Bektas, H., Him, A., et al. (2013). Investigation of the hepatoprotective effects of sesame (Sesamum indicum L.) in carbon tetrachloride-induced liver toxicity. J. Membrane Biol. 246, 1-6. doi: 10.1007/s00232-012-9494-7

Chang, F.-R., Chen, J.-L., Chiu, H.-F., Wu, M.-J., and Wu, Y.-C. (1998). Acetogenins from seeds of Annona reticulata. Phytochemistry 47, 1057-1061. doi: 10.1016/S0031-9422(98)80072-1

Chavan, S. S., Shamkuwar, P. B., Damale, M. G., and Pawar, D. P. (2014). A comprehensive review on Annona reticulata. Int. J. Pharm. Sci. Res. 5, 45-50.

Chen, Y., Huang, B., He, J., Han, L., Zhan, Y., and Wang, Y. (2011). In vitro and in vivo antioxidant effects of the ethanolic extract of Swertia chirayita. J. Ethnopharmacol. 136, 309-315. doi: 10.1016/j.jep.2011. 04.058

Cheng, N., Ren, N., Gao, H., Lei, X., Zheng, J., and Cao, W. (2013). Antioxidant and hepatoprotective effects of Schisandra chinensis pollen extract on CCl4induced acute liver damage in mice. Food Chem. Toxicol. 55, 234-240. doi: 10.1016/j.fct.2012.11.022

Choudhury, A. J., Gogoi, D., Chutia, J., Kandimalla, R., Kalita, S., Kotoky, J., et al. (2016). Controlled antibiotic-releasing Antheraea assama silk fibroin suture for infection prevention and fast wound healing. Surgery 159, 539-547. doi: 10.1016/j.surg.2015.07.022

Choudhury, B., Kandimalla, R., Bharali, R., Monisha, J., Kunnumakkara, A. B., Kalita, K., et al. (2016). Anticancer activity of Garcinia morella on T-Cell murine lymphoma via apoptotic induction. Front. Pharmacol. 7:3. doi: 10.3389/fphar.2016.00003

Edwards, M. J., Keller, B. J., Kauffman, F. C., and Thurman, R. G. (1993). The involvement of kupffer cells in carbon tetrachloride toxicity. Toxicol. Appl. Pharm. 119, 275-279. doi: 10.1006/taap.1993.1069

Feng, Y., Wang, N., Ye, X., Li, H., Feng, Y., Cheung, F., et al. (2011). Hepatoprotective effect and its possible mechanism of Coptidis rhizome aqueous extract on carbon tetrachloride-induced chronic liver hepatotoxicity in rats. J. Ethnopharmacol. 138, 683-690. doi: 10.1016/j.jep.2011. 09.032

Ha, H. L., Shin, H. J., Feitelson, M. A., and Yu, D. Y. (2010). Oxidative stress and antioxidants in hepatic pathogenesis. World J. Gastroenterol. 28, 6035-6043. doi: 10.3748/wjg.v16.i48.6035

Hic, P., and Balic, J. (2012). Effect of sample dilution on estimated values of antioxidant capacity by photochemiluminiscence method. Acta Univ. Agric. Silvic. Mendelianae. Brun. 8, 67-72. doi: 10.11118/actaun201260080067

Hisham, A., Sunitha, C., Sreekala, U., Pieters, L., De Bruyen, T., Van Den Heuvel, H., et al. (1994). Reticulacinone, an acetogenin from Annona reticulata. Phytochemistry 35, 1325-1329. doi: 10.1016/S0031-9422(00)94847-7
Miss. BC, and Mr. SM helped Mr. RK in all the experiments conducted and preparation of manuscript. Dr. KK performed and analyzed the histopathology of liver. Professor JK and Professor $\mathrm{SD}$ supervised the all experimental work and corrected the manuscript.

\section{ACKNOWLEDGMENTS}

The authors are thankful to Institute of Advanced Study in Science and Technology, Guwahati, Assam for support and Department of Science and Technology (DST), New Delhi, India for financial assistance.

Hou, F., Zhang, R., Zhang, M., Su, D., Wei, Z., Deng, Y., et al. (2013) Hepatoprotective and antioxidant activity of anthocyanins in black rice bran on carbon tetrachloride-induced liver injury in mice. J. Funct. Food 5, 1705-1713. doi: 10.1016/j.jff.2013.07.015

Huang, G., Pan, C., Liu, F., Wu, T., and Wu, C. (2012). Anti-inflammatory effects of ethanolic extract of Antrodia salmonea in the lipopolysaccharide-stimulated RAW246.7 macrophages and the k-carrageenan-induced paw edema model. Food Chem. Toxicol. 50, 1485-1493. doi: 10.1016/j.fct.2012.01.041

Ishiyama, H., Sato, M., Matsumura, K., Sento, M., Keiki, O., and Hobara, T. (1995). Proliferation of hepatocytes and attenuation from carbon tetrachloride hepatotoxicity by gadolinium chloride in rats. Basic Clin. Pharmacol. Toxicol. 77, 293-298. doi: 10.1111/j.1600-0773.1995.tb01030.x

Jamkhande, P. G., and Wattamwar, A. S. (2015). Annona reticulata Linn. (Bullock's heart): plant profile, phytochemistry and pharmacological properties. J. Tradit. Complement Med. 5, 144-152. doi: 10.1016/j.jtcme.2015.04.001

Jamkhande, P. G., Wattamwar, A. S., Kankudte, A. D., Tidke, P. S., and Kalaskar, M. G. (2016). Assessment of Annona reticulata Linn. Leaves fractions for invitro antioxidative effect and antimicrobial potential against standard human pathogenic strains. Alexandria J. Med. 52, 19-25.

Kalita, H., Boruah, D. C., Deori, M., Hazarika, A., Sarma, R., Kumari, S., et al. (2016). Antidiabetic and antilipidemic effect of Musa balbisiana root extract: a potent agent for glucose homeostasis in Streptozotocin induced diabetic rat. Front. Pharmacol. 7:102. doi: 10.3389/fphar.2016.00102

Kalita, S., Devi, B., Kandimalla, R., Sharma, K. K., Sharma, A., Kalita, K., et al. (2015). Chloramphenicol encapsulated in poly- $\varepsilon$ - caprolactone-pluronic composite: nanoparticles for treatment of MRSA-infected burn wounds. Int. J. Nanomedicine 10, 2971-2984. doi: 10.2147/IJN.S75023

Kalita, S., Kandimalla, R., Sharma, K. K., Kataki, A. C., Deka, D., and Kotoky, J. (2016). Amoxicillin functionalized gold nanoparticles reverts MRSA resistance. Mater. Sci. Eng. C Mater. Biol. Appl. 61, 720-727. doi: 10.1016/j.msec.2015.12.078

Kandimalla, R., Kalita, S., Choudhury, B., Devi, D., Kalita, D., Kalita, K., et al. (2016). Fiber from ramie plant (Boehmeria nivea): a novel suture biomaterial. Mater. Sci. Eng. C Mater. Biol. Appl. 62, 816-822. doi: 10.1016/j.msec.2016.02.040

Krithikaa, R., Mohankumarb, R., Vermaa, R. J., Shrivastavc, P. S., Mohamadd, I. M., Gunasekarand, P., et al. (2009). Isolation, characterization and anti- oxidative effect of phyllanthin against CCl4-induced toxicity in HepG2 cellline. Chem. Biol. Interact. 181, 351-358. doi: 10.1016/j.cbi.2009.06.014

Kuete, V., and Efferth, T. (2010). Cameroonian medicinal plants: pharmacology and derived natural products. Front. Pharmacol. 1:123. doi: $10.3389 /$ fphar.2010.00123

Liu, J., Jia, L., Kan, J., and Jin, C. (2013). In vitro and in vivo antioxidant activity of ethanolic extract of white button mushroom (Agaricus bisporus). Food Chem. Toxicol. 51, 310-316. doi: 10.1016/j.fct.2012.10.014

Marroquin-Segura, R., Flores-Pimentel, M., Carreón-Sánchez, R., Garcia-Burciaga, M. M., Mora-Guevara, J. L. A., Aguilar-Contreras, A., et al. (2009). The effect of the aqueous extract of Helietta parvifolia A. Gray (Rutaceae) stem bark on carrageenan-induced paw oedema and granuloma tissue formation in mice. J. Ethnopharmacol. 2009, 639-641. doi: 10.1016/j.jep.2009.06.004 
Meir, S., Kanner, J., Akiri, B., and Hadas, S. P. (1995). Determination and involvement of aqueous reducing compounds in oxidative defense systems of various senescing leaves. J. Agric. Food Chem. 43, 1813-1817. doi: 10.1021/jf00055a012

Nirmal, S. A., Gaikwad, S. B., Dhasade, V. V., Dhikale, R. S., Kotkar, P. V., and Dighe, S. S. (2010). Anthelmintic activity of Annona reticulata leaves. Res. J. Pharm. Biol. Chem. Sci. 1, 115-118.

Oyaizu, M. (1986). Studies on products of browning reaction Antioxidtive activities of browning reaction products prepared from glucoseamine. Jpn. J. Nutr. 44, 307-315. doi: 10.5264/eiyogakuzashi.44.307

Pareek, A., Ashok, G., Roshan, I., and Nagori, B. P. (2013). Antioxidant and hepatoprotective activity of Fagonia schweinfurthii (Hadidi) Hadidi extract in carbon tetrachloride induced hepatotoxicity in HepG2cell line and rats. J. Ethnopharmacol. 150, 973-981. doi: 10.1016/j.jep.2013.09.048

Rambabu, V., and Vijayakumar, S. (2014). In vitro cytotoxicity perspective of diazepinomicin (ECO-4601) on human hepatoma cell line (HEPG2). Biomed. Aging Pathol. 4, 65-70. doi: 10.1016/j.biomag.2013.10.004

Su, X. Y., Wang, Z. Y., and Liu, J. R. (2009). In vitro and in vivo antioxidant activity of Pinus koraiensis seed extract containing phenolic compounds. Food Chem. 117, 681-686. doi: 10.1016/j.foodchem.2009.04.076

Vuda, M., D’Souza, R., Upadhya, S., Kumar, V., Rao, N., Kumar, V., et al. (2012). Hepatoprotective and antioxidant activity of aqueous extract of Hybanthus enneaspermus against CCl4-induced liver injury in rats. Exp. Toxicol. Pathol. 64, 855-859. doi: 10.1016/j.etp.2011.03.006

Wele, A., Mayer, C., Quentin, D., Zhang, Y., Blond, A., and Bodo, B. (2009). 3D-structure of cycloreticulin $\mathrm{C}$ and glabrin $\mathrm{A}$, cyclopeptides from the seeds of Annona reticulata. Tetrahedron. 65, 275-281. doi: 10.1016/j.tet.2008. 10.055

Xia, D. Z., Zhang, P. H., Fu, Y., Yu, W. F., and Ju, M. T. (2013). Hepatoprotective activity of puerarin against carbon tetrachloride-induced injuries in rats: a randomized controlled trial. Food Chem. Toxicol. 59, 90-95. doi: 10.1016/j.fct.2013.05.055

Conflict of Interest Statement: The authors declare that the research was conducted in the absence of any commercial or financial relationships that could be construed as a potential conflict of interest.

Copyright (c) 2016 Kandimalla, Dash, Kalita, Choudhury, Malampati, Kalita and Kotoky. This is an open-access article distributed under the terms of the Creative Commons Attribution License (CC BY). The use, distribution or reproduction in other forums is permitted, provided the original author(s) or licensor are credited and that the original publication in this journal is cited, in accordance with accepted academic practice. No use, distribution or reproduction is permitted which does not comply with these terms. 